\title{
INFLUENCE OF SOUS VIDE TREATMENT AND HIGH PRESSURE PROCESSING ON NUTRITIONAL VALUE AND OVERALL ACCEPTANCE OF PULSE SPREADS
}

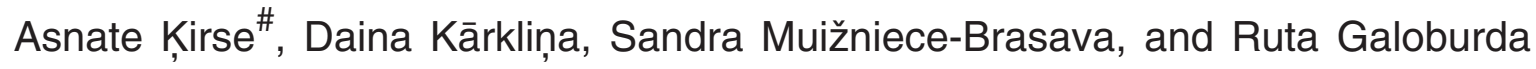 \\ Faculty of Food Technology, Latvia University of Agriculture, 22 Rīgas Str., Jelgava, LV-3004, LATVIA \\ \# Corresponding author, asnate.kirse@ Ilu.Iv
}

Contributed by Daina Kārkliṇa

\begin{abstract}
The study was carried out to investigate the influence of sous vide treatment $\left(80^{\circ} \mathrm{C} / 15 \mathrm{~min}\right)$ and high pressure processing $\left(700 \mathrm{MPa} / 10 \mathrm{~min} / 20^{\circ} \mathrm{C}\right)$ on nutritional characteristics of cowpea (Vigna unguiculata (L.) Walp. cv. Fradel) and maple pea (Pisum sativum var. arvense L. CV. Bruno) spreads after processing and 62-day storage at $5 \pm 1{ }^{\circ} \mathrm{C}$ temperature, to evaluate overall acceptance of processed pulse spreads after 22-day storage and to analyse nutrient coverage of pulse spreads compared to reference intake for adolescents and adults. Pulse spreads were made of cooked pulse seeds to which salt, citric acid, oil, and seasoning was added. Pulse spreads were hermetically sealed under vacuum in PA/PE and PET/ALU/PA/PP pouches. Nutritional composition was determined according to standard methods; overall acceptance was determined using a 5-point hedonic scale. Nutrient coverage by one serving of pulse spreads for adolescents and adults was compared to nutrient recommendations given by the Ministry of Health of the Republic of Latvia. The results suggest that processing technologies and packaging materials did not influence nutritional value of pulse spreads $(p>0.1)$. Hedonic evaluation by consumers $(n=90)$ showed that processing technologies did not influence the overall acceptance of cowpea and maple pea spreads $(p>0.1)$.
\end{abstract}

Key words: cowpea, maple pea, processing technology, reference intake, hedonic scale.

\section{INTRODUCTION}

Pulses or grain legumes are dicotyledonous seeds of plants belonging to the Leguminosae family, harvested for the dry grain and mainly cultivated for human consumption (Hoover et al., 2010). Pulses are the edible seeds of certain leguminous plants including various beans, peas, and lentils. Pulses are rich sources of plant-based protein and essential amino acids, dietary fibre, and carbohydrates with relevant amounts of vitamins and minerals (Chung and Liu, 2012). They have a high protein content $(20-50 \%)$ in comparison to other crops and therefore are consumed in many parts of the world (Singh et al., 2004). They are an important constituent of the human diet worldwide, especially in the countries where alternative sources of protein are limited. Pulse products have the opportunity to increase pulse consumption by excluding time-consuming preparation (Kouris-Blazos and Belski, 2016), however, without additional treatment shelf-life of innovative pulse spreads is up to five days (Kirse and Karklina, 2015).

Thermal and non-thermal processing technologies are suitable for processing of most food products. High pressure processing is a novel non-thermal processing technology that has been available for more than 100 years (Rivalain et al., 2010) and during the last decades commercially adopted to process a wide variety of foods (Georget et al., 2015). Sous vide treatment is a fairly recent thermal processing method, which is characterised as pasteurisation of vacuum packed product in flexible packaging using precisely controlled heating (Baldwin, 2012; Espinosa et al., 2015). The method has gained worldwide recognition in catering establishments (Díaz et al., 2011). Both technologies offer opportunities for increased shelf-life and preservativefree stabilisation of animal and plant based products without a significant influence on nutritional components of foodstuff and sensory parameters (Baldwin, 2012; Georget et al., 2015).

The aim of this study was to determine the influence of sous vide treatment $\left(80^{\circ} \mathrm{C} / 15 \mathrm{~min}\right)$ and high pressure processing (700 MPa/10 $\mathrm{min} / 20{ }^{\circ} \mathrm{C}$ ) on nutritional characteristics of cowpea (Vigna unguiculata (L.) Walp. cv. Fradel) and maple pea (Pisum sativum var. arvense L. cv. Bruno) spreads after processing and 62-day storage at $5 \pm 1{ }^{\circ} \mathrm{C}$ temperature, to evaluate overall acceptance of pulse spreads after 22-day storage at $5 \pm 1{ }^{\circ} \mathrm{C}$ temperature, and to analyse nutrient coverage of pulse spreads compared to reference intake (RI) for adolescents and adults. 


\section{MATERIALS AND METHODS}

Experimental design. The experiments on pulse spreads were carried out at the Faculty of Food Technology, Latvia University of Agriculture in 2016. Pulse spreads were made from cowpeas (Vigna unguiculata (L.) Walp. cv. Fradel), harvested at Universidade de Trás-os-Montes e Alto Douro in 2015, Portugal and maple peas (Pisum sativum var. arvense L. cv. Bruno), harvested at Institute of Agricultural Resources and Economics in 2015, Priekul,i, Latvia, with the following additional ingredients - canola oil (Iecavnieks Ltd., Latvia), citric acid (Spilva, Ltd. Latvia), Himalayan salt (Pakistan), and bruschetta (dried tomato, garlic, and basil) seasoning (P.P.H. fleischmann schaft ${ }^{\circledR}-$ Polska Sp. z o.o., Poland).

Preparation of pulse spreads. Cowpeas and maple peas were soaked in water (with added $\mathrm{NaHCO}_{3}, 21.5 \mathrm{~g} \cdot \mathrm{kg}^{-1}$ ) at $20 \pm 2{ }^{\circ} \mathrm{C}$ for $15 \mathrm{~h}$, then rinsed and boiled in a pressure cooker (KMZ, USSR) until tender (about $35 \pm 5$ min plus $15 \mathrm{~min}$ for natural pressure release). Warm cooked pulses were homogenised in a food processor Philips HR 7761/00 (Philips, The Netherlands) together with salt and citric acid. Seasoning was added to the pulse paste; oil was added at the end of mixing in the food processor (Kirse et al., 2015). Four different pulse spreads were made: cowpea spread, cowpea spread with seasoning, maple pea spread, and maple pea spread with seasoning. Spreads without seasoning consisted of $93.5 \%$ cooked pulses, $5.9 \%$ canola oil, $0.4 \%$ salt and $0.2 \%$ citric acid. Spreads with seasoning consisted of $92.5 \%$ cooked pulses, $5.9 \%$ canola oil, $0.4 \%$ salt, $0.2 \%$ citric acid, and $1 \%$ bruschetta seasoning.

Each sample was packaged in two different flexible packaging films - transparent polyamide / polyethylene (PA/PE) film pouches (film thickness $60 \pm 3 \mu \mathrm{m}$, PTC Ltd.) and lightproof polyethylene terephthalate / aluminium / polyamide / polypropylene (PET/ALU/PA/PP) film pouches (film thickness $80 \pm 3 \mu \mathrm{m}$, Nordvak Ltd., Latvia), pouch dimensions $45 \times 170 \mathrm{~mm} ; \mathrm{m}_{\text {spread }}=50 \pm 1 \mathrm{~g}$. Pulse spread pouches were hermetically sealed under vacuum (20 mbar, sealing time $1.9 \mathrm{~s}$ for PA/PE and $3.4 \mathrm{~s}$ for PET/ALU/PA/PP) using a chamber type vacuum packaging machine (C300, Multivac Ltd., UK) and subjected to additional treatment.

Sous vide processing. Sous vide treatment of pulse spreads was carried out in a water bath Clifton Food Range (Nickel-Electro Ltd., UK). Samples were pasteurised for 15 $\min$ at $80.0 \pm 0.5^{\circ} \mathrm{C}$ temperature (the core temperature 76.0 $\pm 1.0{ }^{\circ} \mathrm{C}$ ). After pasteurisation, the packages were immediately chilled to sample temperature $5.0 \pm 1.0{ }^{\circ} \mathrm{C}$ in +2 $\pm 1{ }^{\circ} \mathrm{C}$ cold ice-water (Kirse et al., 2015).

High pressure processing. High pressure processing of pulse spreads was carried out using an Iso-Lab High Pressure Pilot Food Processor S-FL-100-250-09-W (Stansted Fluid Power Ltd., Essex, UK) in a 2.0 L pressure vessel. An isopropanol: water mix $(1: 2)$ was used as the pressure transmitting liquid (Kirse et al. 2015). Pouches of pulse spreads were placed in a pressure vessel and treated at 700 MPa with 10 min dwell time. Pascalisation was carried out at room temperature, however, due to pressure increase in the vessel, it reached $40-42{ }^{\circ} \mathrm{C}$ during pressurisation.

Storage of processed pulse spreads. Sous vide treated and high pressure processed samples were stored at $5.0 \pm 1.0^{\circ} \mathrm{C}$ (temperature recorded by MINILog, GHM Messtechnik $\mathrm{GmbH}$ Standort Greisinger, Germany) in a commercial display cooler (Snaige Ltd., Lithuania) with tempered glass door under daylight luminescence with radiant fix at 400 to 1000 lx (measured by LX-107 Portable Digital Light meter, Lutron Electronic Enterprise Co., Ltd., Taiwan). Nutritional composition was determined on day 0 and 62 . Overall acceptance was determined after a 22-day storage period.

Determination of nutritional composition and energy value calculation. Nutritional composition was determined according to standard methods: protein concentration (ISO 20483:2013), fat concentration (ISO 11085:2008), total dietary fibre concentration (AOAC 985.29-1986), ash concentration (ISO 2171:2007), and moisture (ISO 24557:2009); available carbohydrates $(\%)$ were determined by difference (Anonymous, 2003) according to the formula:

Available carbohydrates $=100-(m+p+l+a+d f)$,

where $m$ - moisture concentration, $p$ - protein concentration, $\%, l$ - lipid concentration, $\%, a-$ ash concentration, $\%$, $d f$ - dietary fibre concentration, $\%$.

Energy value of pulse spreads was calculated according to coefficients described in European Union Regulation No. 1169/2011: carbohydrates $17 \mathrm{~kJ} \cdot \mathrm{g}^{-1}$; protein $17 \mathrm{~kJ} \cdot \mathrm{g}^{-1}$; fat $37 \mathrm{~kJ} \cdot \mathrm{g}^{-1}$ and dietary fibre $8 \mathrm{~kJ} \cdot \mathrm{g}^{-1}$ (Anonymous, 2011).

Nutritional evaluation of pulse spreads in comparison to nutrient recommendations. The calculation of the optimal nutrient amount (recommended daily intake of nutrients expressed as reference intake (RI)) for adolescents and adults (Table 1) was completed based on the ordinance No. 174 "Recommended allowance of energy and nutrients for Latvian citizens", issued by Ministry of Health of the Republic of Latvia on 15 October 2008 (Anonymous, 2008). Calculations were carried out in both groups per gender (female and male) and average values were used for further analysis.

Table 1

RECOMMENDED ENERGY AND NUTRIENT INTAKE (Ordinance No $174 / 2008$ )

\begin{tabular}{|c|c|c|c|c|}
\hline Age group & $\begin{array}{c}\text { Energy }(\mathrm{E}) \text {, } \\
\text { kcal }\end{array}$ & Protein, E\% & Fat, E\% & $\begin{array}{l}\text { Carbohy- } \\
\text { drates, E\% }\end{array}$ \\
\hline \multicolumn{5}{|l|}{ Adolescent } \\
\hline - female & 2400 & $10-15^{*}$ & $30-35^{*}$ & $50-55^{*}$ \\
\hline - male & 3000 & & & \\
\hline \multicolumn{5}{|l|}{ Adult } \\
\hline - female & 2000 & $10-15^{*}$ & $25-30^{*}$ & $55-60^{*}$ \\
\hline - male & 2400 & & & \\
\hline
\end{tabular}


Evaluation of overall acceptance. Sensory analysis of high pressure processed pulse spreads was carried out using a 5-point hedonic scale during the international Baltic food industry fair "Riga Food 2016" (90 consumer panellists; $60 \%$ women and $40 \%$ men, average age 32 years). Consumer respondents were from all regions of Latvia: Kurzeme (19\%), Zemgale (26\%), Vidzeme (20\%), Latgale $(10 \%)$, and Rìga (25\%). Consumers were also asked to describe likes and dislikes about pulse spreads and the likelihood to purchase these products at a grocery store and consume them on a daily basis. Collated scores were compared to the data from a previous study on overall acceptance of pulse spreads after sous vide treatment (Kirse et al., 2016).

Software And Data Processing. Data processing was carried out using mathematical and statistical methods with statistical software $R$ 3.0.2; differences were considered significant at $p \leq 0.05$, unless stated otherwise. Differences among nutritional value of different pulse spreads were analysed using One-way analysis of variance and the Tukey's test.

\section{RESULTS}

In order to calculate nutritional value of pulse spreads, such parameters as moisture, protein, lipids, ash and dietary fibre were determined in all spread samples on day 0 (Table 2) and on day 62 (Table 3). The result of the proximate chemical composition of pulse spreads indicated that the spreads contained $67.31 \pm 0.40 \%$ moisture, $7.31 \pm 0.14 \mathrm{~g}$ protein, $6.08 \pm 0.02 \mathrm{~g}$ lipids, $1.04 \pm 0.02 \mathrm{~g}$ ash, and $12.87 \pm 1.47 \mathrm{~g}$ dietary fibre per $100 \mathrm{~g}$. The influence of sous vide treatment and high pressure processing on moisture, protein, lipid, ash, and dietary fibre concentration of all investigated pulse spreads was not significant after processing $(p>0.1)$, comparing untreated pulse spreads to processed samples (Table $2)$. The chosen packaging materials did not have an influence on these parameters as well $(p>0.1)$. The effect of processing technologies and packaging materials on chemical parameters of pulse spreads was insignificant after 62-day storage $(p>0.1)$ (Table 3). Therefore, nutritional value of pulse spreads was calculated based on nutrient values of untreated samples (Table 4). Dietary fibre concentration was higher in both spreads made from maple peas compared to cowpea spreads $(p=0.013)$. Spreads made from maple pea had lower available carbohydrate concentration than cowpeas spreads $(p=0.016)$. Energy value of pulse spreads ranged from 537.51 to $550.56 \mathrm{~kJ} \cdot 100 \mathrm{~g}^{-1}$ with no significant differences $(p>0.05)$.

Coverage (\%) of protein, fat, dietary fibre, available carbohydrates and energy of one serving $(50 \mathrm{~g})$ of pulse spreads in comparison to RI was calculated based on nutrient values of untreated samples (Table 4). Recommended daily energy intake for adolescent females and adult males is $10042 \mathrm{~kJ}$ per day, while the amount is lower for adult females and higher for adolescent males: $8368 \mathrm{~kJ}$ per day and $12552 \mathrm{~kJ}$ per day, respectively (Table 1). Recommended daily intake

Table 2

MOISTURE CONTENT AND CHEMICAL COMPOSITION OF UNTREATED AND PROCESSED PULSE SPREADS IN DIFFERENT PACKAGING MATERIALS AFTER PROCESSING (DAY 0)

\begin{tabular}{|c|c|c|c|c|c|c|c|}
\hline \multicolumn{2}{|c|}{ Sample } & \multicolumn{5}{|c|}{ Processing treatment and packaging material } & \multirow[t]{2}{*}{$p$} \\
\hline & & $\mathrm{I}$ & II & III & IV & $\mathrm{V}$ & \\
\hline \multirow[t]{3}{*}{ Moisture (\%) } & $\mathrm{CS}$ & $67.60 \pm 0.04$ & $67.56 \pm 0.03$ & $67.58 \pm 0.05$ & $67.51 \pm 0.09$ & $67.60 \pm 0.03$ & 0.742 \\
\hline & MS & $66.92 \pm 0.09$ & $66.94 \pm 0.08$ & $66.97 \pm 0.10$ & $66.97 \pm 0.06$ & $66.91 \pm 0.05$ & 0.844 \\
\hline & MSS & $66.91 \pm 0.02$ & $66.86 \pm 0.05$ & $66.85 \pm 0.08$ & $66.89 \pm 0.06$ & $66.88 \pm 0.02$ & 0.795 \\
\hline \multirow{4}{*}{ Protein $\left(\mathrm{g} \cdot 100 \mathrm{~g}^{-1}\right)$} & CS & $7.30 \pm 0.03$ & $7.29 \pm 0.04$ & $7.30 \pm 0.10$ & $7.31 \pm 0.09$ & $7.33 \pm 0.11$ & 0.544 \\
\hline & CSS & $7.17 \pm 0.04$ & $7.18 \pm 0.07$ & $7.20 \pm 0.07$ & $7.21 \pm 0.06$ & $7.17 \pm 0.06$ & 0.656 \\
\hline & MS & $7.44 \pm 0.06$ & $7.43 \pm 0.10$ & $7.42 \pm 0.05$ & $7.42 \pm 0.02$ & $7.40 \pm 0.02$ & 0.626 \\
\hline & MSS & $7.35 \pm 0.04$ & $7.36 \pm 0.06$ & $7.34 \pm 0.03$ & $7.35 \pm 0.03$ & $7.32 \pm 0.01$ & 0.501 \\
\hline \multirow[t]{3}{*}{ Lipids $\left(\mathrm{g} \cdot 100 \mathrm{~g}^{-1}\right)$} & $\mathrm{CS}$ & $6.10 \pm 0.07$ & $6.07 \pm 0.06$ & $6.05 \pm 0.09$ & $6.07 \pm 0.03$ & $6.11 \pm 0.05$ & 0.605 \\
\hline & CSS & $6.07 \pm 0.02$ & $6.06 \pm 0.05$ & $6.06 \pm 0.10$ & $6.08 \pm 0.02$ & $6.07 \pm 0.04$ & 0.931 \\
\hline & MS & $6.09 \pm 0.04$ & $6.07 \pm 0.05$ & $6.06 \pm 0.08$ & $6.08 \pm 0.04$ & $6.05 \pm 0.10$ & 0.870 \\
\hline \multirow[t]{4}{*}{$\operatorname{Ash}\left(\mathrm{g} \cdot 100 \mathrm{~g}^{-1}\right)$} & $\mathrm{CS}$ & $1.06 \pm 0.02$ & $1.05 \pm 0.02$ & $1.04 \pm 0.02$ & $1.06 \pm 0.03$ & $1.03 \pm 0.02$ & 0.701 \\
\hline & CSS & $1.05 \pm 0.02$ & $1.04 \pm 0.02$ & $1.04 \pm 0.02$ & $1.03 \pm 0.03$ & $1.04 \pm 0.02$ & 0.895 \\
\hline & MS & $1.04 \pm 0.02$ & $1.03 \pm 0.02$ & $1.02 \pm 0.01$ & $1.02 \pm 0.02$ & $1.03 \pm 0.02$ & 0.901 \\
\hline & MSS & $1.08 \pm 0.03$ & $1.05 \pm 0.03$ & $1.03 \pm 0.02$ & $1.04 \pm 0.02$ & $1.04 \pm 0.01$ & 0.792 \\
\hline \multirow{4}{*}{$\begin{array}{l}\text { Dietary fibre } \\
\left(\mathrm{g} \cdot 100 \mathrm{~g}^{-1}\right)\end{array}$} & $\mathrm{CS}$ & $11.58 \pm 0.08$ & $11.55 \pm 0.10$ & $11.56 \pm 0.12$ & $11.56 \pm 0.14$ & $11.53 \pm 0.11$ & 0.678 \\
\hline & CSS & $11.42 \pm 0.10$ & $11.40 \pm 0.12$ & $11.42 \pm 0.10$ & $11.44 \pm 0.14$ & $11.40 \pm 0.06$ & 0.701 \\
\hline & MS & $14.33 \pm 0.14$ & $14.30 \pm 0.10$ & $14.30 \pm 0.11$ & $14.28 \pm 0.05$ & $14.33 \pm 0.05$ & 0.691 \\
\hline & MSS & $14.06 \pm 0.10$ & $14.10 \pm 0.12$ & $14.11 \pm 0.15$ & $14.06 \pm 0.06$ & $14.08 \pm 0.03$ & 0.614 \\
\hline
\end{tabular}

CS, cowpea spread; CSS, cowpea spread with seasoning; MS, maple pea spread; MSS, maple pea spread with seasoning. I, control; II, sous vide treatment, $\mathrm{PA} / \mathrm{PE}$; III, sous vide treatment, PET/ALU/PA/PP; IV, high pressure processing, PA/PE; V, high pressure processing, PET/ALU/PA/PP 
Table 3

MOISTURE CONTENT AND CHEMICAL COMPOSITION OF UNTREATED AND PROCESSED PULSE SPREADS IN DIFFERENT PACKAGING MATERIALS AFTER STORAGE (DAY 62)

\begin{tabular}{|c|c|c|c|c|c|c|}
\hline \multicolumn{2}{|c|}{ Sample } & \multicolumn{4}{|c|}{ Processing treatment and packaging material } & \multirow[t]{2}{*}{$p$} \\
\hline & & II & III & IV & $\mathrm{V}$ & \\
\hline \multirow[t]{3}{*}{ Moisture (\%) } & CS & $67.54 \pm 0.02$ & $67.53 \pm 0.04$ & $67.46 \pm 0.05$ & $67.59 \pm 0.02$ & 0.736 \\
\hline & MS & $66.92 \pm 0.03$ & $66.95 \pm 0.02$ & $66.95 \pm 0.05$ & $66.90 \pm 0.03$ & 0.840 \\
\hline & MSS & $66.84 \pm 0.02$ & $66.83 \pm 0.06$ & $66.85 \pm 0.05$ & $66.87 \pm 0.05$ & 0.781 \\
\hline \multirow[t]{4}{*}{ Protein $\left(\mathrm{g} \cdot 100 \mathrm{~g}^{-1}\right)$} & CS & $7.30 \pm 0.07$ & $7.30 \pm 0.13$ & $7.30 \pm 0.12$ & $7.31 \pm 0.08$ & 0.540 \\
\hline & CSS & $7.18 \pm 0.03$ & $7.19 \pm 0.10$ & $7.19 \pm 0.08$ & $7.18 \pm 0.05$ & 0.661 \\
\hline & MS & $7.42 \pm 0.05$ & $7.42 \pm 0.08$ & $7.41 \pm 0.07$ & $7.43 \pm 0.10$ & 0.612 \\
\hline & MSS & $7.35 \pm 0.05$ & $7.34 \pm 0.07$ & $7.34 \pm 0.09$ & $7.33 \pm 0.08$ & 0.550 \\
\hline \multirow[t]{3}{*}{ Lipids (g.100 $\mathrm{g}^{-1}$ ) } & $\mathrm{CS}$ & $6.06 \pm 0.08$ & $6.04 \pm 0.09$ & $6.06 \pm 0.03$ & $6.07 \pm 0.06$ & 0.612 \\
\hline & CSS & $6.06 \pm 0.06$ & $6.04 \pm 0.02$ & $6.08 \pm 0.03$ & $6.07 \pm 0.06$ & 0.831 \\
\hline & MS & $6.06 \pm 0.08$ & $6.03 \pm 0.10$ & $6.08 \pm 0.05$ & $6.06 \pm 0.07$ & 0.862 \\
\hline \multirow[t]{4}{*}{$\operatorname{Ash}\left(\mathrm{g} \cdot 100 \mathrm{~g}^{-1}\right)$} & CS & $1.04 \pm 0.02$ & $1.04 \pm 0.02$ & $1.05 \pm 0.04$ & $1.03 \pm 0.03$ & 0.710 \\
\hline & CSS & $1.03 \pm 0.02$ & $1.03 \pm 0.01$ & $1.03 \pm 0.04$ & $1.03 \pm 0.03$ & 0.876 \\
\hline & MS & $1.03 \pm 0.02$ & $1.02 \pm 0.03$ & $1.03 \pm 0.03$ & $1.03 \pm 0.01$ & 0.890 \\
\hline & MSS & $1.03 \pm 0.03$ & $1.04 \pm 0.02$ & $1.03 \pm 0.02$ & $1.05 \pm 0.02$ & 0.785 \\
\hline \multirow{4}{*}{$\begin{array}{l}\text { Dietary fibre } \\
\left(\mathrm{g} \cdot 100 \mathrm{~g}^{-1}\right)\end{array}$} & $\mathrm{CS}$ & $11.50 \pm 0.08$ & $11.52 \pm 0.08$ & $11.54 \pm 0.09$ & $11.54 \pm 0.03$ & 0.662 \\
\hline & CSS & $11.42 \pm 0.10$ & $11.41 \pm 0.09$ & $11.44 \pm 0.10$ & $11.41 \pm 0.03$ & 0.710 \\
\hline & MS & $14.29 \pm 0.06$ & $14.30 \pm 0.08$ & $14.29 \pm 0.08$ & $14.32 \pm 0.03$ & 0.667 \\
\hline & MSS & $14.11 \pm 0.10$ & $14.11 \pm 0.12$ & $14.06 \pm 0.10$ & $14.04 \pm 0.06$ & 0.633 \\
\hline
\end{tabular}

CS, cowpea spread; CSS, cowpea spread with seasoning; MS, maple pea spread; MSS, maple pea spread with seasoning. II, sous vide treatment; PA/PE, III, sous vide treatment, PET/ALU/PA/PP; IV, high pressure processing, PA/PE; V, high pressure processing, PET/ALU/PA/PP

for fat of total energy intake is higher for adolescents. The coverage of nutrients by one serving $(50 \mathrm{~g})$ of pulse spreads was analysed in comparison to reference intake values of nutrients for adolescents and adults (Table 5).

The results showed that a serving of pulse spreads (50 g) covered 3.7-4.6\% protein for adolescents and 4.9-5.6\% protein for adults (Fig. 1). A serving of pulse spreads covered $2.7-3.4 \%$ fat for adolescents and $4.1-4.9 \%$ fat for adults, while carbohydrate coverage was $0.7-0.9 \%$ for adolescents and adults. The coverage of energy of a serving of pulse spreads was $2.2-3.3 \%$ for adolescents and adults. An adequate intake of dietary fibre is $14 \mathrm{~g}$ per $1000 \mathrm{kcal}$ for children and adults (Dahl and Stewart, 2015). The content of dietary fibre in pulse spreads is high (Table 4), therefore the coverage of dietary fibre (Fig. 2) is also higher compared to other nutrients. A serving (50 g) of cowpea spreads covered 13.7-17.1\% dietary fibre for adolescents and $17.1-20.5 \%$ dietary fibre for adults, while a serving of maple pea spreads covered $16.9-21.1 \%$ and $21.1-25.4 \%$ dietary fibre for adolescents and adults, respectively.

With regard to hedonic evaluation of processed pulse spreads (Table 6), the results showed that overall preference of high pressure processed cowpea spread was between 'not sure' to 'like a little' (3.8) and cowpea spread with seasoning- 'like a little' to 'like very much' (4.5). Consumers liked cowpea spread with seasoning (CS) better $(p<0.05)$ compared to cowpea spread without seasoning (CSS). Overall
Table 4

NUTRITIONAL VALUE OF PULSE SPREADS

\begin{tabular}{|c|c|c|c|c|c|}
\hline \multirow{2}{*}{$\begin{array}{l}\text { Nutritional } \\
\text { parameters }\end{array}$} & \multicolumn{4}{|c|}{ Pulse spreads } & \multirow[t]{2}{*}{0} \\
\hline & CS & CSS & MS & MSS & \\
\hline Protein, $\mathrm{g} \cdot 100 \mathrm{~g}^{-1}$ & 7.30 & 7.17 & 7.44 & 7.35 & 0.261 \\
\hline Dietary fibre, $\mathrm{g} \cdot 100 \mathrm{~g}^{-1}$ & $11.58^{\mathrm{a}}$ & $11.42^{\mathrm{a}}$ & $14.33^{\mathrm{b}}$ & $14.06^{\mathrm{b}}$ & 0.013 \\
\hline Fat, $\mathrm{g} \cdot 100 \mathrm{~g}^{-1}$ & 6.10 & 6.07 & 6.09 & 6.09 & 0.895 \\
\hline $\begin{array}{l}\text { Available carbohydrates, } \\
\mathrm{g} \cdot 100 \mathrm{~g}^{-1}\end{array}$ & $6.36^{\mathrm{a}}$ & $6.58^{\mathrm{a}}$ & $4.18^{\mathrm{b}}$ & $4.51^{\mathrm{b}}$ & 0.016 \\
\hline Energy, $\mathrm{kJ} \cdot 100 \mathrm{~g}^{-1}$ & 550.56 & 549.70 & 537.51 & 539.43 & 0.112 \\
\hline Energy, kcal $100 \mathrm{~g}^{-1}$ & 132.70 & 132.47 & 129.95 & 130.37 & 0.134 \\
\hline
\end{tabular}

CS, cowpea spread; CSS, cowpea spread with seasoning; M, maple pea spread; MSS, maple pea spread with seasoning. a, b-different subscript letters within a row indicate significant differences at $p<0.05$.

Table 5

RECOMMENDED DAILY INTAKE OF NUTRIENTS (G PER DAY)

\begin{tabular}{l|c|c|c|c}
\hline Age group & Protein & Fat & $\begin{array}{c}\text { Dietary } \\
\text { fibre }\end{array}$ & Carbohydrates \\
\hline Adolescent & \multicolumn{5}{l}{} \\
\hline $\begin{array}{l}\text { female } \\
\text { male }\end{array}$ & 80 & 90 & 33.6 & 320 \\
\hline Adult & 100 & 113 & 42 & 400 \\
\hline $\begin{array}{l}\text { female } \\
\text { male }\end{array}$ & 65 & 62 & 28 & 295 \\
& 75 & 75 & 33.6 & 355
\end{tabular}




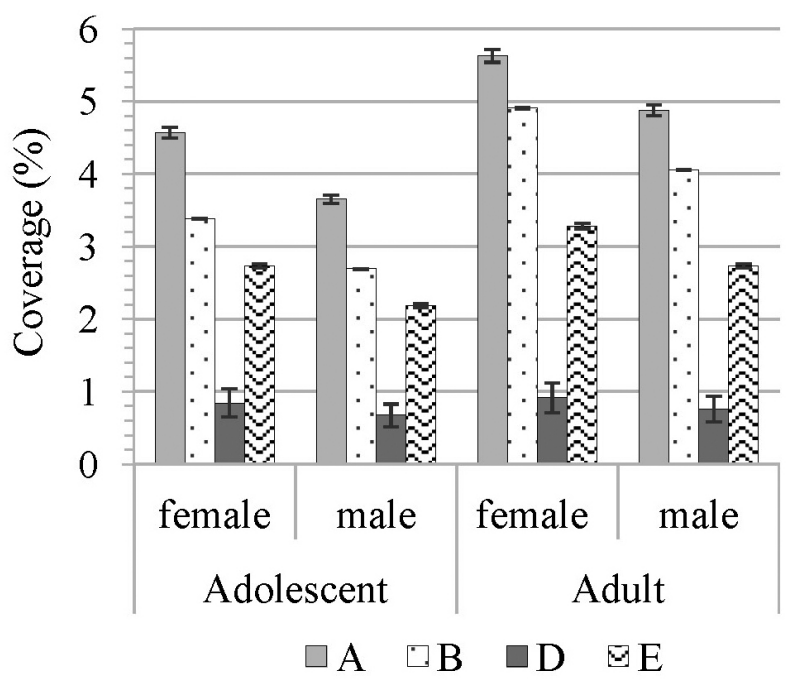

Fig. 1. Coverage (\%) of protein (A), fat (B), available carbohydrates (C) and energy (D) of one serving (50 g) of pulse spreads (on average) in comparison to reference intake.

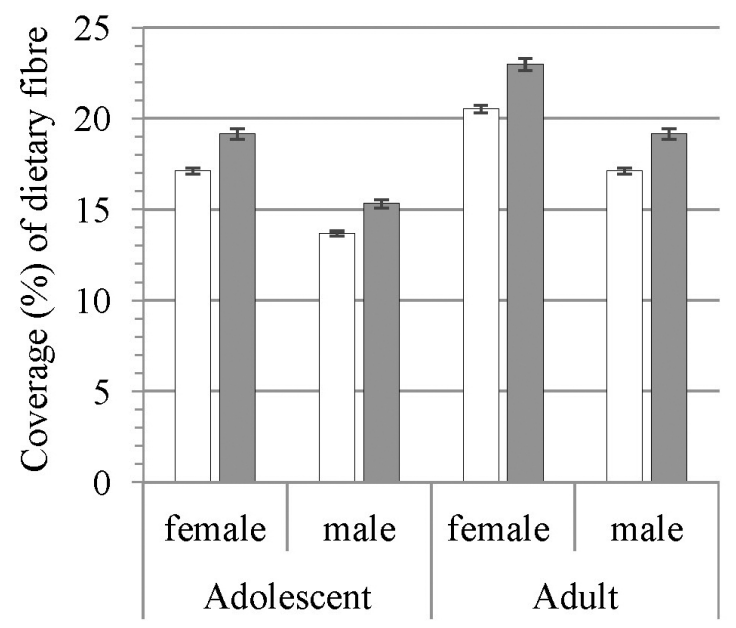

Fig. 2. Coverage (\%) of dietary fibre of one serving (50 g) of pulse spreads made from cowpeas $(\square)$ and maple peas $(\square)$ in comparison to reference intake.

Table 6

RESULTS OF HEDONIC EVALUATION OF PULSE SPREADS BY CONSUMERS

\begin{tabular}{l|cccc}
\hline \multirow{2}{*}{ Processing treatment } & \multicolumn{4}{|c}{ Degree of preference/liking } \\
\cline { 2 - 5 } & CS & CSS & MS & MSS \\
\hline Fresh/untreated (Kirse et al., 2016) & $3.8^{\mathrm{a}}$ & $4.4^{\mathrm{b}}$ & $4.6^{\mathrm{b}}$ & $4.8^{\mathrm{b}}$ \\
Sous vide treatment (Kirse et al., 2016) & $3.8^{\mathrm{a}}$ & $4.5^{\mathrm{b}}$ & $4.5^{\mathrm{b}}$ & $4.6^{\mathrm{b}}$ \\
High pressure processing & $4.0^{\mathrm{a}}$ & $4.5^{\mathrm{b}}$ & $4.5^{\mathrm{b}}$ & $4.7^{\mathrm{b}}$ \\
\hline
\end{tabular}

CS, cowpea spread; CSS, cowpea spread with seasoning; MS, maple pea spread; MSS, maple pea spread with seasoning. a, b - different subscript letters with a column indicate significant differences at $p<0.05$.

preference of high pressure processed pulse spreads made from maple peas was between 'like a little' to 'like very much' (4.5-4.7), without significant differences between both spreads $(p>0.05)$. The main positive aspects of pulse spreads reported by consumer respondents were: aroma $(\mathrm{n}=34)$, pleasantly mild taste $(\mathrm{n}=58)$, plant based product $(n=60)$, vegan product $(n=56)$, consistency and mouthfeel $(n=49)$, whereas some respondents wanted a more noticeable taste of seasoning $(n=16)$. The likelihood to purchase these products at a grocery store was affirmed by the majority of the respondents (78\%); the rest of the respondents were indecisive. The majority of the consumers $(83 \%)$ also confirmed they would like to consume the new products on a daily basis.

\section{DISCUSSION}

Pulses are nutrient-rich food and are valued all over the world for their protein concentration and low glycaemic index. Protein concentration in legume grains ranges from $17 \%$ to $40 \%$ (Costa de Almeida et al., 2006), whereas carbohydrates constitute the major fraction of pulse seeds within the range of 24-68\% (Piecyk et al., 2012). From the nutrition point of view, only thermally processed pulses are important since pulses are never eaten raw (Wang et al. 2008); therefore, the concentration of protein and carbohydrates of pulses is proportionally lower (on fresh weight). The values of protein, ash and dietary fibre concentration, established in the current study, are comparable to the literature data (McCrory et al., 2010; Kirse and Karklina, 2013) where grain legumes and spreads from pulses are indicated as good sources of nutrients. A previous study on white bean (Phaseolus vulgaris L.) spreads showed that protein content was not dependent on seasonings used (Kirse and Karklina, 2015) and was not significantly different between cowpea and maple pea spreads. Based on the findings that sous vide treatment and high pressure processing did not influence nutritional composition after processing and 62-day storage, it is possible to conclude that the chosen thermal treatment and high pressure processing regimes are suitable to maintain consistent product (chemical composition) quality after additional processing and storage.

The values of nutrients of pulse spreads (Table 4) allows to apply nutritional claims defined in Regulation (EC) No. 1924/2006 (Anonymous, 2006). The Regulation indicates the possibility to define a product as a 'source of protein' if it provides at least $12 \%$ of the energy value by protein, and as a 'high protein' if the product provides at least $20 \%$ of the energy value by protein. The protein content of all four pulse spreads accomplished the requirements for a nutritional 'high protein', as $21.7-22.9 \%$ of the energy value of pulse spreads was provided by protein. The same regulation allows labelling of all developed pulse spreads as 'high fibre' if they contain $\geq 6.0 \mathrm{~g}$ of fibre per $100 \mathrm{~g}$. When pulse spreads are compared to other similar products on the market (Kirse and Karklina, 2014b), such as 'Hum-Hum' Hummus (Zila Laguna, Latvia) and 'WD fit' soy spread (W-D, Poland), the new spreads are also eligible for an 'energy-reduced' claim, which describes food with energy value reduced by at least $30 \%$ with an indication of the characteristic(s) that make(s) the food reduced in its total energy value. Both spreads on the market contain a fair amount of lipids (22 to $29 \mathrm{~g}$ per $100 \mathrm{~g}$ ) (Kirse and Karklina, 
2014b), thus making pulse spreads 'energy-reduced' by 45 to $60 \%$.

The results of nutrient coverage (\%) by one serving (50 g) of pulse spreads (Figs. 1,2) were different among age and gender groups, as recommended energy and nutrient intake (Table 1) varies between adolescents and adults. Adolescence is a nutritionally vulnerable developmental stage because growth rate accelerates (Gidding et al., 2005). Higher caloric requirements are needed for adolescent males since they experience greater increases in height, weight, and lean body mass compared to adolescent females (Stang and Story, 2005). The lowest coverage of all nutrients was found for adolescent males, because the requirements for all investigated nutrients in this group were the highest; whereas the highest coverage of all nutrients was found for adult females. The coverage of carbohydrates available for human digestion was below 1\%, indicating that all pulse spreads are low in available carbohydrates. Pulses spreads are a good source of dietary fibre for all investigated age and gender groups (Fig. 2), especially for female adults, as one serving of maple pea spreads covers $1 / 4$ of their dietary fibre daily needs.

Overall acceptance and sensory parameters of products are closely related to product demand; therefore, consumer acceptance research is particularly important in the new product development process. The results of hedonic evaluation of pulse spreads showed that overall acceptance of the new products was not affected by additional processing compared to fresh samples. A previous study (Kirse and Karklina, 2015) also established that spreads made from maple peas are preferred over cowpea spreads, especially cowpea spread without seasoning. The results suggest that high pressure processing does not influence the overall acceptance of pulse products compared to untreated samples and sous vide pulse spreads. Previous studies (Kirse and Karklina, 2014a; Kirse et al., 2016) on the acceptance of new pulse spreads showed that the majority of the consumer respondents would buy spreads made from white beans, cowpeas and maple peas as soon as these products were available at a grocery store and would consume these spreads on a daily basis.

\section{ACKNOWLEDGMENTS}

The research was supported by the FP7 Research Project No. 613781 "Eurolegume - Enhancing of legumes growing in Europe through sustainable cropping for protein supply for food and feed".

\section{REFERENCES}

Anonymous (2003). FAO Food and Nutrition Paper No 77. Food energymethods of analysis and conversion factors: Report of a technical workshop. Food and Agriculture Organization of the United Nations (FAO), Rome. 93 pp.

Anonymous (2006). European Commission (EC). Regulation (EC) No $1924 / 2006$ of the European Parliament and of the Council of 20 December
2006 on nutrition and health claims made on foods. OJ EU, L 404, 49 , 9-25.

Anonymous (2008). Ieteicamās enerğijas un uzturvielu devas Latvijas iedzīvotājiem [Recommended allowance of energy and nutrition for Latvian citizens]. Ordinance No. 174 issued by Ministry of Health of the Republic of Latvia on 15 October 2008. Available from:

http://www.vm.gov.lv/images/userfiles/ieud.pdf (accessed 15 November 2017) (in Latvian).

Anonymous (2011). European Union (EU). Regulation (EU) No. 1169/2011 of the European Parliament and of the Council of 25 October 2011 on the provision of food information to consumers, amending Regulations (EC) No. 1924/2006 and (EC) No. 1925/2006 of the European Parliament and of the Council, and repealing Commission Directive 87/250/EEC, Council Directive 90/496/EEC, Commission Directive 1999/10/EC, Directive 2000/13/EC of the European Parliament and of the Council, Commission Directives 2002/67/EC and 2008/5/EC and Commission Regulation (EC) No 608/2004 Text with EEA relevance. OJ EU L 304, 54, 18-63.

Baldwin, D. E. (2012). Sous vide cooking: A review. Int. J. Gastron. Food Sci., 1, 15-30.

Chung, H. J., Liu, Q. (2012). Physicochemical properties and in vitro digestibility of flour and starch from pea (Pisum sativum L.) cultivars. Int. J. Biol. Macromol., 50, 131-137.

Dahl, W. J., Stewart, M. L. (2015). Position of the Academy of Nutrition and Dietetics: Health implications of dietary fiber. J. Acad. Nutr. Dietetics, 115 (11), 1861-1870.

Díaz, P., Garrido, M. D., Bańon, S. (2011) Spoilage of sous vide cooked salmon (Salmo salar) stored under refrigeration. Food Sci. Technol. Int., 17, 31-37.

Espinosa, M. C., Díaz, P., Linares, M. B., Teruel, M. R., Dolores, M. (2015). Quality characteristics of sous vide ready to eat seabream processed by high pressure. LWT — Food Sci. Technol., 64, 657-662.

Georget, E., Sevenich, R., Reineke, K., Mathys, A., Heinz, V., Callanan, M., Rauh, C., Knorr, D. (2015). Inactivation of microorganisms by high isostatic pressure processing in complex matrices: A review. Innovative Food Sci. Emerging Technol., 27, 1-14.

Gidding, S. S., Dennison, B. A., Birch, L. L., Daniels, S. R., Gilman, M. W., Lichtenstein, A. H., Rattay, K. T., Steinberger, J., Stettler, N., Van Horn, L. (2005). Dietary recommendations for children and adolescents. Circulation, 112, 2061-2075.

Hoover, R., Hughes, T., Chung, H. J., Liu, Q. (2010). Composition, molecular structure, properties, and modification of pulse starches: A review. Food Res. Int., 43, 399-413.

Kirse, A., Karklina D., Muizniece-Brasava, S. (2016). Consumer acceptance of new pulse spreads before and after sous vide treatment. J. Int. Sci. Publ. Agriculture Food, 4, 104-114.

Kirse, A., Karklina, D. (2013). Quality evaluation of new vegetarian bean spreads. Eur. Sci. J., 4, 453-457.

Kirse, A., Karklina, D. (2014a). Attitudes of Latvian adults to the consumption of pulses. In: Proceedings of the Annual $20^{\text {th }}$ International Scientific Conference: Research for Rural Development 2014, 19-21 May 2014, Jelgava. Latvia University of Agriculture, Jelgava, pp. 130-137.

Kirse, A., Karklina, D. (2014b). Nutritional evaluation of pulse spreads in comparison to nutrient recommendations. In: Proceedings of the $9^{\text {th }}$ Baltic Conference on Food Science and Technology: Food for consumer well-being - FoodBalt 2014, 8-9 May 2014, Jelgava. Latvia University of Agriculture, Jelgava, pp. 138-143.

Kirse, A., Karklina, D. (2015). Integrated evaluation of cowpea (Vigna unguiculata (L.) Walp.) and maple pea (Pisum sativum var. arvense L.) spreads. Agron. Res., 13 (4), 956-968.

Kirse, A., Karklina, D., Muizniece-Brasava, S., Galoburda, R. (2015). High pressure processing for pea spread shelf life extension: a preliminary study. GRANT J., 4 (2), 102-108. 
Kouris-Blazos, A., Belski, R. (2016). Health benefits of legumes and pulses with a focus on Australian sweet lupins. Asia Pacif. J. Clin. Nutr., 25 (1), $1-17$.

McCrory, M. A., Hamaker, B. R., Lovejoy, J. C., Eichelsdoerfer, P. E. (2010). Pulse consumption, satiety, and weight management. Advances Nutr., 1, 17-30.

Piecyk, M., Wołosiak, R., Drużynska, B., Worobiej, E. (2012). Chemical composition and starch digestibility in flours from Polish processed legume seeds. Food Chem., 135 (3), 1057-1064.

Received 4 October 2016

Accepted in the final form 16 November 2017
Rivalain, N., Roquain, J., Demazeau, G. (2010). Development of high hydrostatic pressure in biosciences: Pressure effect on biological structures and potential applications in biotechnologies. Biotechnol. Adv., 28, 659-672.

Singh, N., Sandhu, K. S., Kaur, M. (2004). Characterization of starches separated from Indian chickpea (Cicer arietinum L.) cultivars. J. Food Eng., 63, 441-449.

Stang, J., Story, M. (2005). Nutrition Needs of Adolescents. In: Stang, J., Story, M. (eds.). Guidelines for Adolescent Nutrition Services. University of Minnesota, Minneapolis, pp. 21-34.

Wang, N., Hatcher, D. W., Gawalko, E. J. (2008). Effect of variety and processing on nutrients and certain anti-nutrients in field peas (Pisum sativum). Food Chem., 111, 132-138.

\section{SOUS VIDE UN AUGSTSPIEDIENA APSTRĀDES IETEKME UZ PĀKŠAUGU PASTĒŠU UZTURVĒRTĪBU UN PATIKŠANAS PAKĀPI}

Pētījuma mērkis bija noteikt sous vide apstrādes $\left(80^{\circ} \mathrm{C} / 15 \mathrm{~min}\right)$ un augstspiediena tehnoloǵijas $\left(700 \mathrm{MPa} / 10 \mathrm{~min} / 20{ }^{\circ} \mathrm{C}\right)$ ietekmi uz melnacoto pupiṇu (Vigna unguiculata (L.) Walp. cv. Fradel) un pelēko zirņu (Pisum sativum var. arvense L. cv. Bruno) pastēšu uzturvērtỉbu pēc apstrādes un 62 dienu uzglabāšanas $5 \pm 1{ }^{\circ} \mathrm{C}$ temperatūrā, novērtēt apstrādātu pākšaugu pastēšu patikšanas pakāpi pēc 22 dienu uzglabāšanas, kā arī analizēt pākšaugu pastēšu uzturvielu segumu salīdzinājumā ar ieteicamo devu pusaudžiem un pieaugušajiem. Pākšaugu pastētes gatavotas no vārītiem pākšaugiem, kam pievienots sāls, citonskābe, ellla un garšvielas. Pākšaugu pastētes iepakotas PA/PE un PET/ALU/PA/PP maisiņos un hermētiski aizkausētas vakuumā. Uzturvielu sastāvs noteikts saskaṇā ar standartmetodēm; patikšanas pakāpe noteikta, izmantojot 5 punktu hedonisko skalu. Vienas pākšaugu pastētes porcijas uzturvielu segums pusaudžiem un pieaugušajiem salīdzināts ar Veselības ministrijas izstrādātajiem uzturvielu ieteikumiem. Rezultāti norāda, ka apstrādes tehnoloğijas un iepakošanas materiāli neietekmē pākšaugu pastēšu uzturvērtību $(p>0.1)$. Patērētāju $(\mathrm{n}=90)$ hedoniskais vērtējums rāda, ka apstrādes tehnoloğijas neietekmē melnacoto pupiṇu un pelēko zirṇu pastēšu patikšanas pakāpi $(p>0.1)$. 